\title{
A very rare case of cervicothoracic vertebral synostosis spanning eight adjacent segments: congenital vs acquired
}

\author{
Sekiz ardış1k segmenti kapsayan çok nadir bir servikotorakal vertebral sinostoz olgusu: \\ konjenital mi, edinsel mi? \\ İsmet CENGİÇ, Derya TÜRELİ, Hilal ALTAŞ, Onur BUĞDAYCI
}

\begin{abstract}
An elderly female presented with acute post-traumatic neck pain. Cervical roentgenogram revealed a long-segment cervicothoracic vertebral fusion spanning 8 adjacent spinal levels. The patient was evaluated with computed tomography $(\mathrm{CT})$ and magnetic resonance (MR) imagings of the spine, electromyography (EMG) and growth differentiation factor 6 (GDF6) gene mutation analysis. Imaging findings were atypical for congenital block vertebrae and there was no GDF6 mutation. A revision of very old medical records and patient's recollections revealed long-term stay in sanatorium for rehabilitation of chronic partially-treated brucella spondylodiscitis during adolescence. Block vertebrae spanning several levels have previously been reported; but, this is the first report of an acquired cervicothoracic fusion spanning 8 adjacent vertebral bodies.

Keywords: Cervicothoracic vertebral synostosis, Klippel - Feil syndrome, Magnetic resonance imaging, Brucellosis, Growth differentiation factor 6
\end{abstract}

\section{İsmet Cengiç}

Radiology Clinic, Van Training and Research Hospital, Van, Turkey

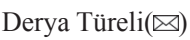

Department of Radiology,, Koç University Hospital, Istanbul, Turkey

mail:deryatureli@yahoo.com

Hilal Altaş

Department of Radiology, School of Medicine, Ordu University, Ordu, Turkey

Onur Buğdayc1

Department of Radiology, School of Medicine, Marmara University, Istanbul, Turkey

Submitted / Gönderilme: 24.08.2017

Accepted/Kabul: 29.11.2017
ÖZ

Yaşlı bir kadın hasta travma sonrası akut boyun ağrısı ile başvurdu. Servikal direkt grafisinde 8 ardışı spinal seviyeyi kapsayan uzun segment servikotorakal vertebral füzyon saptandi. Hasta spinal bilgisayarlı tomografi (BT) ve magnetik rezonans (MR) görüntüleme, elektromiyografi (EMG), ve büyüme-farklılaşma faktörü 6 [Growth differentiation factor 6 (GDF6)] gen mutasyonu analizi ile detaylı tetkik edildi. Görüntüleme bulguları konjenital blok vertebra için atipik olan olguda GDF6 gen mutasyonu saptanmadı. Hastanın eski tıbbi raporları ve anamnezinde adolesan dönemde kronik ve kısmen tedavi edilmiş brucella spondilodiskiti rehabilitasyonu amaciyla sanatoryumda uzun dönemli yatış mevcut idi. Birkaç seviyeyi kapsayan blok vertebra olguları daha önceden bildirilmiş olmakla birlikte; bu, 8 ardışı vertebral cismi kapsayan ilk edinsel servikotorakal füzyon olgusudur.

Anahtar kelimeler: Servikotorakal vertebral siyanoz, KlippelFeil sendromu, Magnetik rezonans görüntüleme, Brusellozis, Büyüme-farklılaşma faktörü 6

\section{Introduction}

The cervical spine is one of the most frequently imaged body areas due to ubiquity of painful symptomatology originating from the neck region. The cervical spine, despite its relative morphological stability may exhibit many congenital or acquired segmentation anomalies [1]. We present a very rare case of cervicothoracic block vertebrae spanning 8 vertebral levels.

\section{Case Report}

A 76-year-old woman, brought to the emergency room (ER) by paramedics presented with neck pain due to acute blunt trauma. She had skid on ice and hit her neck on the railing of stairs. 
Patient had a slightly kyphotic and short neck. Range of motion was limited in lower cervical levels. Physical examination was otherwise unremarkable. Neurologic examination was within normal limits. A plain x-ray of the neck revealed a long segment cervicothoracic vertebral fusion (Figure 1).

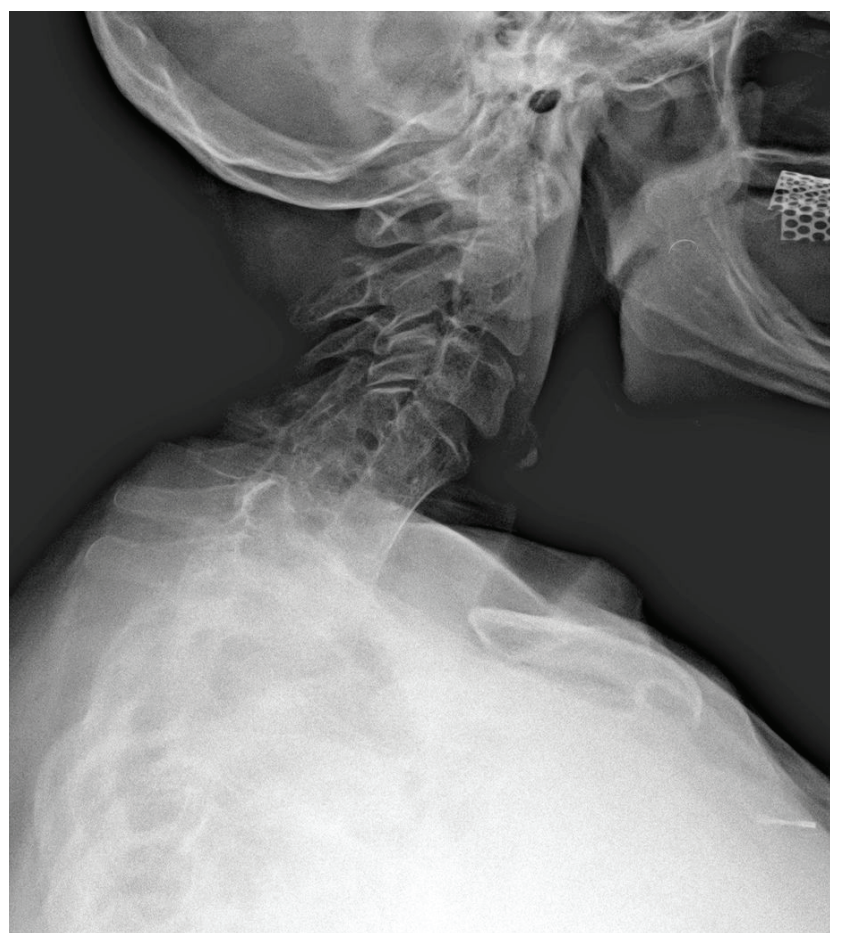

Figure 1. Plain roentgenogram of the neck, lateral view. Long segment cervicothoracic vertebral fusion starting from C4 level. No signs of osseous trauma evident.

Mechanism of injury and her symptoms required computed tomography (CT) of the cervical spine which revealed a complete fusion of 8 vertebral bodies from $\mathrm{C} 4$ to T4 levels (Figure 2). Posterior vertebral elements were spared and there were no traumatic vascular or osseous injuries. She did not need further evaluation or treatment in the ER and was scheduled for outpatient follow-up.

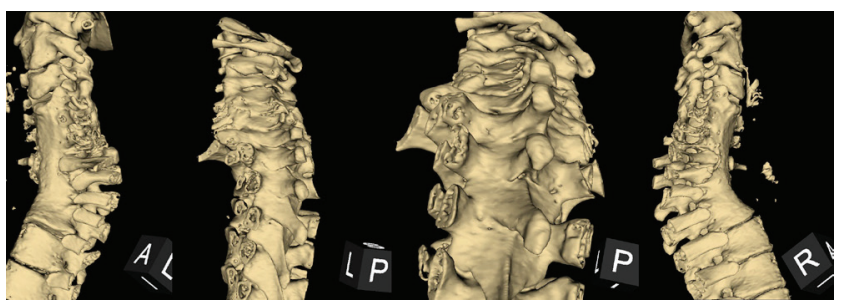

Figure 2. Computed tomography of the vertebral column, 3D isosurface rendered images. There is complete fusion of vertebral bodies $\mathrm{C} 4$ through T4. Posterior arch elements, however, appear separate. There are no missing vertebral segments as evidenced by the spinous processes.
Written informed consent was obtained prior to further outpatient work-up. Pain related to trauma had subsided significantly. Magnetic resonance imaging (MRI) of the whole spine confirmed previous CT findings (Figure 3). There were no additional spinal segmentation anomalies. Electromyography (EMG) of the upper extremities were within normal limits. Echocardiography was normal. Abdominal and neck sonography revealed no additional anomalies. Growth differentiation factor 6 (GDF6) gene mutation analysis using Sanger sequencing by capillary electrophoresis, though not part of routine work-up for Klippel-Feil Syndrome Type 1, was performed for academic research purposes; results were negative.

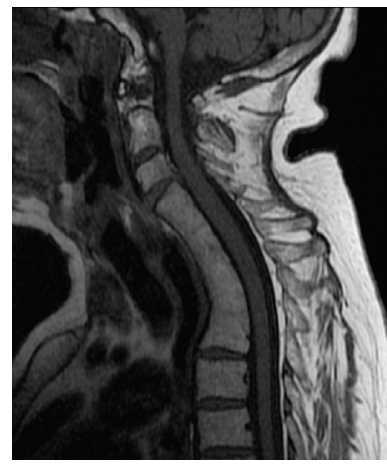

(a)

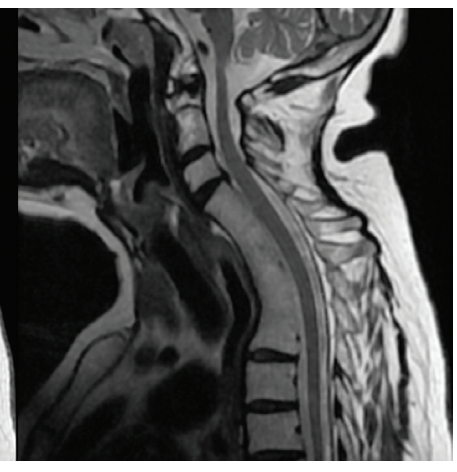

(b)
Figure 3. Magnetic resonance imaging of the cervicothoracic vertebral column, (a)sagittal T1-weighted and (b) sagittal T2-weighted images. Note complete fusion of vertebral bodies C4 through T4. Wasp-waist sign is absent and there is shortening of the vertebral column. Curvature of the affected segment is kyphotic. Spinal canal width is preserved and the spinal cord is normal.

Patient's detailed medical history revealed no prior trauma to the neck. A revision of very old medical records revealed a four-month stay in a sanatorium for rehabilitation of chronic non-tuberculous infectious disease and her diagnosis of brucellosis in 1953. She recounted having swollen and painful neck with restricted motion for several months during early adolescence. She also described waxing and waning fevers, sweating, joint pain, severe myalgia, and weight loss overlapping the period she was institutionalized. These symptoms were consistent with brucellosis, once a highly endemic disease in the region, further supporting partiallytreated chronic brucella spondylodiscitis as the etiology.

\section{Discussion}

Block vertebrae is a vertebral anomaly where two or more adjacent bodies are partially or completely fused. This may 
be due to segmentation anomalies in utero or acquired later in life [2]. Klippel-Feil syndrome is generally accepted as an all-inclusive diagnosis for all patients with a congenital fusion of the cervical spine, regardless of the presence of a classic triad of short neck, low-set posterior hair line, and decreased cervical motion [3]. Acquired causes of cervical block vertebrae include a variety of entities such as postinfectious, post-traumatic, postsurgical fusion, fibrodysplasia ossificans progressiva, juvenile rheumatoid arthritis, diffuse idiopathic skeletal hyperostosis (DISH) and ossification of posterior longitudinal ligament (OPLL) [4].

It is easy to detect block vertebrae, but it may be difficult to determine whether it is congenital or acquired $[4,5]$. However, there are certain clues for differential diagnosis. Congenital block vertebrae are frequently associated with hemivertebrae, absent vertebra above or below the fused segments, and fusion of posterior elements. These findings are absent in acquired cases [2]. Klippel-Feil syndrome is frequently associated with anomalies in other systems and there is evidence of genetic predisposition to this condition. These are not prominent in cases of acquired fusion [6]. A pathognomonic radiographic appearance seen in patients with congenital block vertebrae is the wasp-waist sign: The anterior concave indentation at the site of the absent or reduced interspace between the fused segments, with a smooth anteriorly concave surface forming a seamless arc along the anterior vertebral aspect. Wasp-waist sign is not seen with acquired fusion due to infectious or inflammatory etiology $[4,7,8]$. In congenital block vertebrae, total height of fused segment is equal to the sum of involved vertebral bodies and intervertebral discs between them. In acquired fusion, on the other hand, this height is less than that of congenital fusion [4].

This is the first case report of an acquired cervicothoracic fusion spanning 8 adjacent vertebral bodies. Klippel-Feil syndrome was ruled-out due to following reasons: Posterior elements were intact and wasp-waist sign was absent. Height of fused segments were shorter than expected for congenital fusion and intervertebral disc spaces were non-existent. No associated congenital anomalies of other systems were detected. Genetic analysis was also negative for GDF6 gene mutation.
Patient's medical records and recollections were consistent with brucellosis. She had lived in a remote rural setting during immediate post-World War II era, thus was unable to attain optimal medical treatment. She had to be institutionalized for rehabilitation of brucella spondylodiscitis, a not-so-rare complication of partiallytreated or untreated chronic brucellosis, an infectious granulomatous disease which was once very common and still endemic to some extent - even in post-antibiotic era in the very countryside.

\section{Disclosure of interest}

The authors declare that they have no conflicts of interest concerning this article.

\section{References}

1. Thawait GK, Chhabra A, Carrino JA. Spine segmentation and enumeration and normal variants. Radiol Clin North Am 2012;50:587-98. doi: 10.1016/j.rcl.2012.04.003

2. Kumar R, Guinto FC, Jr, Madewell JE, Swischuk LE, David R. The vertebral body: radiographic configurations in various congenital and acquired disorders. Radiographics 1988;8:455-85. doi:10.1148/radiographics.8.3.3380991

3. Klimo P Jr, Rao G, Brockmeyer D. Congenital anomalies of the cervical spine. Neurosurg Clin N Am 2007;18:463-78. doi:10.1016/j.nec.2007.04.005

4. Nguyen VD, Tyrrel R. Klippel-Feil syndrome: patterns of bony fusion and wasp-waist sign. Skeletal Radiol 1993;22:519-23.

5. Guille JT, Sherk HH. Congenital osseous anomalies of the upper and lower cervical spine in children. J Bone Joint Surg Am 2002;84-A:277-88.

6. Yuksel M, Karabiber H, Yuksel KZ, Parmaksiz G. Diagnostic importance of 3D CT images in Klippel-Feil Syndrome with multiple skeletal anomalies: a case report. Korean J Radiol 2005;6:278-81. doi:10.3348/kjr.2005.6.4.278

7. McBride WZ. Klippel-Feil syndrome.Am Fam Physician 1992;45:633-5.

8. Theiss SM, Smith MD, Winter RB. The long-term follow-up of patients with Klippel-Feil syndrome and congenital scoliosis. Spine (Phila Pa 1976). 1997 ;22:1219-22. 